\title{
9
}

\section{Narrating Asylum in Camp and at Court}

\author{
Matilde Skov Danstrøm and Zachary Whyte
}

\section{Introduction}

Seeking asylum is in fundamental ways a narrative undertaking. After all, the ability to construct a convincing, coherent, and consistent narrative is crucial to a successful asylum claim (Bohmer and Shuman 2008; Eastmond 2007; Good 2007). In Denmark, the Head of the Danish Refugee Appeals Board (RAB) Secretariat, has estimated that 9 out of 10 cases before the $\mathrm{RAB}$ are determined on the basis of credibility (P1 2014). Credibility, in turn, is often determined on the basis of judgments of narrative consistency (are there discrepancies, or 'divergences' as they are termed in the Danish context, in the narrative?) and authorship (does the narrative seem self-experienced?). This raises particular questions as to how narratives are constructed and assessed in the Danish asylum system — and indeed to what extent these two processes are separable. For asylum seekers, this narrative task is made more difficult by the opacity of the asylum system to them. Most cannot easily make sense of the bases for judgment of their asylum motives and this uncertainty fundamentally structures their experiences

M. S. Danstrøm $(\bowtie)$

University of Copenhagen, Copenhagen, Denmark

Z. Whyte

AMIS, University of Copenhagen, Copenhagen, Denmark

e-mail: whyte@hum.ku.dk 
of the system. The lawyers provided for them after an initial rejection are meant to help with this by re-presenting their claims before the RAB. The mediating role the lawyers play sheds light on both the narrative logics of the asylum determination system and the everyday narratives of asylum seekers waiting in asylum centres.

Drawing on ethnographic fieldwork in Denmark, this chapter investigates the ways in which asylum seekers and asylum lawyers present and re-present asylum narratives across two contrasting, yet interlinked, contexts: Danish asylum centres (termed 'camp' by the asylum seekers) and the RAB ('court' to asylum seekers). Among asylum seekers at Danish asylum centres, narratives of asylum almost never include the substance of asylum seekers' legal claims (their asylum motives). Details are guarded, not least from other asylum seekers. The asylum process itself, on the other hand, is a recurring topic, where interpreters, caseworkers and the general attitude of the Danish asylum system are regularly discussed. By contrast, asylum narratives presented at the RAB are meant to focus exclusively on content and performance (which is so crucial to asylum claims, as Kobelinsky, this volume, attests), at least insofar as they relate to the specifics of the asylum seekers' claim as mediated by their asylum lawyers. While context thus strongly shapes the kinds of asylum narratives that are presented and shared, this chapter suggests that themes of uncertainty, credibility and authorship are central both in the Danish asylum process and for the ways in which it is understood by the actors invested in it.

A terminological note is in order from the outset. While we write broadly of 'asylum narratives' as any of a range of narratives associated with the asylum system, we distinguish between two modes of narrating asylum in the two contexts of court and camp, which we might conceive of as stories for and stories of asylum. The first is what lawyers and adjudicators call the 'asylum motive,' that is the narratives processed by the Danish asylum authorities, which form the basis for their decisions on the application. The second is what we term 'asylum talk' which covers the narratives asylum seekers tell each other about the system they are caught up in. These two kinds of narratives are of course quite distinct: They have separate structures, turn-taking conventions, and consequences. They are part of different kinds of narrative exchanges and subject to different sorts of judgments. However, they do also connect and influence each other, if unevenly. The stories asylum seekers tell each other about the asylum system may influence the ways in which they tell their stories in the court setting. Conversely, it is often experiences with the asylum determination system that shape the kinds of stories told in the camps. 
The uneven power relations between the two contexts can be seen in the bearing they have on each other. The judgment of the credibility of the asylum motive at court has profound consequences for the future lives of asylum seekers, while the narratives about asylum in circulation at the camp have little or no effect on the bureaucratic system of judgment. This is illustrated neatly by the fact that while court is a frequent topic of conversation at the camps, life in the camps is largely considered irrelevant at court. This disconnection is in itself important for how asylum seekers view the asylum system. It shapes the kinds of conversations they have about the system, and may thereby also shape the ways in which asylum seekers experience and participate in court proceedings.

\section{A Narrative Approach}

Asylum motives are often the main evidence on which asylum decisions are made (Kjær 2001; Bohmer and Shuman 2010), and narrative approaches naturally have some history in the study of forced migration, particularly when conceived methodologically e.g. as the collection of life stories (Krulfeld and MacDonald 1998; McKinley 1997; Omidian 1994). Narrative approaches to the asylum process have usefully examined issues of credibility (Good 2007), emotion (Kobelinsky 2015), resistance (Smith 2015, 2016) and mistrust (Daniel and Knudsen 1995; Bohmer and Shuman 2008; see also Kobelinsky, this volume). Marita Eastmond (2007), building on Edward Bruner (1986), has scrutinised narrative as a field of knowledge production, which 'provides a site to examine the meanings, which actors ascribe to experience' (2007: 260). Experience, Eastmond argues, gives 'rise and form' to the narratives, but is also 'organised and given meaning' when it is narrated (2007: 249). Eastmond points out that what is remembered and expressed by a narrator is situated in the specific encounter between the narrator and the audience, marked by the power relations between them. What is expressed is affected both by accounts of the past and present, but also by thoughts and dreams of the future (ibid.).

Our approach here differs somewhat in that our primary focus is not so much to understand the experiences of asylum seekers before they came to Denmark, but rather to better understand the Danish asylum system itself. In this chapter, we ask what sorts of narrative conventions structure Danish asylum practice, how are they practised, and how do asylum seekers make sense of these structures? 
Following a brief description of the Danish legal context, we consider the trajectory the asylum motive takes before it reaches the RAB. Our task is not to look at the content of the asylum seekers' life stories as such (Kälin 1986; Blommaert 2001; Ghorashi 2008), but rather to look at the production of the asylum motive as a narrative tool to analyse the systems of judgement. Indeed, we argue that the asylum determination system profoundly shapes the asylum motives, while at the same time ascribing authorship of them solely to the asylum seeker.

We then turn to the narrative work asylum seekers engage in at the camps, as they struggle to make sense of the Danish asylum bureaucracy. Refugee narratives are often judged based on how they conform to standards of 'good' narration (Vogl 2013), but these standards are more visible to asylum lawyers than asylum seekers. Struggling to make sense of these narrative models and to find avenues for action to help guide their cases in a favourable direction, asylum seekers draw on their own experiences and those of others, conveyed through narrative, as they discuss systemic logics, individual caseworkers, and possibilities for action.

Finally, the Refugee Appeals Board serves as a site of narrative judgment, in which various actors work to present and re-represent the asylum motive, ascribed to the asylum seeker. Judgments often turn on the presence of 'divergences' and on whether asylum motives are deemed 'self-experienced.' Here the performance of the asylum motive can play a crucial role in the determination. However, this performance at court takes place as frustration has built among asylum seekers in the camps, and lawyers are particularly alert to the importance of managing the affective presentations of asylum seekers. In this sense, the trajectory of the asylum motive is influenced by the trajectory of what we might call asylum seekers' 'asylum careers', and asylum motives and asylum talk intermingle.

\section{Methods}

This chapter draws on ongoing ethnographic engagement with the Danish asylum context from the two authors. Danstrøm conducted five months of fieldwork in 2012 with Danish asylum lawyers, which included participant observation at the RAB and with asylum lawyers, as well as interviews with lawyers, judges, NGOs, and Immigration Service officials. She was the first researcher to be granted access to the closed RAB hearings, which came about in large part through her participant observation with the asylum lawyers. Whyte originally conducted a year's fieldwork among asylum seekers at 
a Danish asylum centre in 2001-2002, which included participant observation and formal and informal interviews with asylum seekers, Red Cross staff, and Immigration Service caseworkers. Since then, he has continued his engagement with the field, conducting several shorter research projects with asylum seekers and refugees in Denmark. This chapter thus draws both on the authors' original findings and later ethnographic work in various contexts. By juxtaposing these ongoing engagements, we aim to examine the 'linkages' (Colson 2007) that shape the interactions across the two narrative contexts of camp and court. We have anonymised all our informants and cases and use pseudonyms throughout.

\section{Legal Context and Background}

The criteria to achieve refugee status in Denmark are formalised in the Danish Aliens Act (DAA 2016). The Danish system of course draws on the 1951 UN Refugee Convention, and can grant full Convention status under 'Section 7.1' of the Aliens Act. However, a number of subsidiary forms of protection have been added. Thus 'Section 7.2' refers to Article 3 in the European Convention on Human Rights (EC 1950), granting a separate status to a wider group of refugees, while a new 'Section 7.3' was implemented in 2015 to grant temporary protection for one year (to be assessed by the authorities annually). The latter was aimed at the Syrians entering Denmark at the time. These subsidiary forms of status do not all give access to the same range of rights, e.g. to family reunification or welfare services, as Convention status does.

The Danish Immigration Service (DIS), under the Ministry of Integration, processes asylum applications in the first instance in Denmark. Initially, the case will be assessed according to the Dublin regulation, which among other things entails that asylum applications can only be processed in one EU country. DIS can further dismiss cases as 'manifestly unfounded' if they are considered without substance or prospects according to section $53 \mathrm{~b}$. These cases cannot be appealed, but will instead be assessed by an NGO, the Danish Refugee Council, which may refer the case back to the so-called 'normal procedure'.

In the last few years, first instance recognition rates have been exceptionally high. In 2016, $72 \%$ of asylum claims were granted one of the three forms of protection status. However, just five years earlier, in 2011 average recognition rates were only $33 \%$. This change is in large part due to the relatively large number of Syrians and Eritreans, who claimed asylum in the last few years. 
In the normal procedure, a rejection is automatically appealed to a quasi-judicial body, the RAB. Established in 1983, the aim was to have independent adjudicators settle the practice on asylum in Denmark, rather than the previous ad hoc administrative system (Christensen et al. 2006: 464ff.). It is a uniquely Danish construction. In most other European countries asylum rejections can be appealed and processed in (specialised) courts with open hearings. By contrast, RAB hearings take place behind closed doors and with the involvement of both judges and others. It consists of a number of smaller boards, which comprised five members in 2014: a judge from the regular court system, who functions as a chairman; two judicial representatives from the Ministry of Integration and the Ministry of Foreign Affairs respectively; a lawyer from The Danish Bar and Law Society; and lastly a member appointed by the Danish Refugee Council (DRC). The Ministry of Integration is thus represented both by the DIS, presenting the reasons for their first instance rejection, and by a representative sitting on the Board to which that decision is appealed.

However, the number of board members and the institutions they represent have changed several times from seven to three to five members, following shifting political priorities of successive governments. In particular, the members appointed by DRC have been subject to political discussion-and a new amendment to the Aliens Act effective from 1st January 2017 once again removes the DRC members (as well as the Ministry of Foreign Affairs to keep an uneven number). These changes speak directly to the heavily politicised nature of the Danish asylum system.

Another important aspect of the Danish system is that appeals to the $\mathrm{RAB}$ are final. The substance of the cases cannot be appealed beyond the RAB (Section 56, 8 in the Danish Aliens Act (DAA 2016)). The only exceptions are on the basis of complaints concerning procedural irregularities. However, even cases brought on procedural grounds have generally been referred back to the RAB with the conclusion that the complaint was in fact linked to the substance of the case (see note 1008 to Section 56, 8, DAA 2016). Further, cases cannot be taken before the Ombudsman, who can only initiate cases concerning asylum himself (Section 58, DAA 2016). Nevertheless, there are some other options used by asylum seekers and their lawyers. In theory, there is a possibility of getting temporary humanitarian protection upon a separate application (section 9b paragraph 1), though this possibility has been undermined in recent years, and was only granted in 76 cases in 2012 (DIS 2013). Further, asylum seekers can apply for a 'reopening' of their case. However, this requires that 'new substantial information' has come to light in the case. Lastly, if all national options have been 
exhausted, the case could be taken to the UN Committee or the European Court of Human Rights. However, since asylum seekers do not receive legal aid from the Danish state beyond the RAB and this appeal is not suspensive, this is rarely exercised.

\section{The Trajectory of the Asylum Motive}

The asylum motive-what we have called the story for asylum-is not a fixed narrative. Rather, it is ambiguously perpetuated and re-shaped through a number of versions before it reaches the RAB. Jan Blommaert calls this process 'discourse circulation' (2001: 438), stressing the trajectory (cf. Maryns 2006) of the narrative going from oral to written, passing different interlocutors or co-narrators even, including interpreters, along the way. Spotti and Gibb (this volume) explore this process, which they refer to as 'entextualisation', while Dahlvik (this volume) discusses the influence interpreters can have over narratives.

To illustrate these points, it is worth sketching out this trajectory before the motive comes before the RAB. In doing so, one further point must be kept in mind: The asylum motives that come before the RAB are a particular subset of the asylum motives, since they by definition have been rejected in the first instance. While this may speak to the particularities of the case and the credibility of the asylum seeker, we argue that the trajectory itself also shapes the asylum motive, as it is presented and represented through the determination system.

An asylum case in Denmark starts with an initial registration of the claimant by the police, who record their identity and travel route. After the registration, the asylum seeker will be asked to fill out an asylum application form in their native language, if possible. If this is done, it will be translated and serve as the basis for the case throughout the process. A short 'motive and information interview' is then conducted through an interpreter, after which a DIS caseworker summarises the case.

The next version, the asylum interview, is sometimes enacted up to a year after arrival depending on the current caseload. This is carried out by a DIS caseworker (and an interpreter), who questions the asylum seeker in more detail. The caseworker produces a written summary of this interview, which forms the basis for the first instance judgment by the caseworker. This text, in other words, combines summary with judgment. For rejected cases that end up before the RAB, the summaries are often explicitly skeptical of the asylum motive. In one example, the caseworker wrote: 'When asked if the 
applicant does not agree that it seems implausible to be able to see the three men accurately from a 50 meters distance [...]'. Or: 'It seems odd that they would give the applicant a bible only two to three months after they met the first time [...]'. Also phrases like, 'it seems striking' or 'it seems noticeable' are commonly used, as are terms such as 'implausible' and even 'weird' or 'strange'. The language then is often one of disbelief or suspicion tied to particular narrative conventions (Good 2007; Vogl 2013). The representatives from the DIS explained that this line of questioning was meant to help the asylum seeker by giving them a chance to explain what seemed unlikely to the representative. 'It's to be fair to them', as one put it. The lawyers, however, felt that it confused their clients, and some lawyers expressed the concern that this was intended to 'test' the asylum seekers on the motives and provoke the so-called 'divergences' that could undermine the asylum seekers' credibility. As Hanne, an asylum lawyer, put it in frustration with a particular summary, 'In other judicial proceedings, an interrogator would stop the suspects if they were saying things to harm their case before a lawyer was present. But in the DIS it's as if the opposite is the case'. In any case, as we will discuss in the following section, this explicit mistrust is experienced keenly by the asylum seekers themselves.

If a case is rejected in the first instance, it is automatically appealed, and a lawyer is appointed, who receives the existing case files, as do the adjudicators. The lawyer usually has a meeting lasting from two to six hours with the client to go through the case again. On this basis, the lawyer writes a submission to the RAB, summarising the asylum motive yet again, but in a manner designed to support a positive judgment.

Two of the key elements forming the basis for asylum decisions are whether the asylum motive contains 'divergences' and whether it seems 'self-experienced'. These terms tie in closely to concerns with consistency and credibility. As a RAB chairman put it: 'If the asylum seekers' explanations show some significant discrepancies of one kind or another [...], then you can get the suspicion that this in fact is a fabricated asylum motive.'

Susan Coutin has shown in Salvadoran and Guatemalan asylum cases in the US that the smallest 'plot hole' in the narrative can lead to a rejection (2001: 84). The lawyers' job is therefore to sort out the versions from the first instance and frame yet another, in the form of the submission, to address these 'plot holes'. As the lawyer Martin complained, 'We are never invited in until afterwards, right? [...] and if there are the least of divergences between the summary of the [asylum] interview and some report from the police $[\ldots]$ then we are sold. You are out. That is definitely wrong $[. .$.$] '.$ 
This focus on divergences can play out in ways that highlight both issues of interpretation and authorship. An Afghani asylum seeker's interview with DIS was too long to finish in one day, so his interview was split in two sessions with one month between them. In the first summary, it was stated among other details that he had 'a conflict with his relatives'. In the second interview, it was stated that he had 'a conflict with his cousins' and was 'scolded by the local community'. However, the terms 'relatives' and 'cousins' were seen as diverging by the DIS caseworker. At his meeting with his lawyer, the client explained that he used the term 'scolding' [skald ud], in a sense more severe than the Danish translation could capture, meaning something like 'personal threats'. The case was rejected in the RAB as well. In this case, it seems the adjudicators read the translation and the written summaries as if they were the exact words of the asylum seeker. The words were considered his own, though the asylum seeker did not recognise their use or the meaning of the Danish term 'skald ud' - to which he was ascribed authorship.

The perception of divergences in the asylum motive alongside a number of other elements (see below) may lead adjudicators to suggest that the asylum motive is not 'self-experienced'. Indeed, one of the common rejection phrases used is that 'the RAB does not find that the explanations seem self-experienced'. This speaks directly to questions of authorship, suggesting that the asylum seeker is not the proper author of the asylum motive. The bureaucratic and legal practice is quite clear: the asylum motive belongs to the asylum seeker alone and judgments of the asylum motive will determine whether the asylum seeker is granted protection status or not. However, the authorship of the asylum motive is rather more vexed than the asylum system presumes and accepts. Indeed, lawyers complained that the common issues of poor translations in the system, in which interpreters might change aspects of the narrative (see Dahlvik, this volume), carried little weight before the RAB. However, as we have seen, even beyond issues of translation, the asylum motive is co-produced by a range of other actors and is repeatedly represented and summarised in a way that may render it unrecognisable to the asylum seekers themselves. As Bruner has shown, narratives emerge in collaboration between speaker and audience (Bruner 1986). Indeed, the multiple narrative contexts and audiences may risk facilitating the narrative 'divergences' that shape decisions on credibility. Thus the procedure disempowers asylum seekers in putting forward the asylum motive on their own terms (cf. Giordano 2008: 590; Good 2007: 23). While the asylum motive thus risks fragmentation across its trajectory, the different versions are held together by the ascription of authorship to the asylum seeker. 
In practice, then, asylum motives are continually produced in the asylum system through particular narrative contexts, audiences, and modes of questioning, meaning that they reflect not only the experiences the asylum seekers present as a basis for their asylum claim but also the asylum determination system itself. While the experiences narrated are of course not about the asylum system, the manner in which they are presented, the questions asked to elicit them, and especially the ways in which individual experiences are joined to form a narrative- the asylum motive-are structured by the asylum system. The key point here is that there is no 'original' asylum narrative that may be elicited in or twisted by the asylum process. The asylum motive is a narrative that only makes sense within the asylum determination process.

Before discussing how the assessment takes place before the RAB we look at how the tales of the asylum system, asylum talks, circulate in the asylum centres and how this circulation is somewhat separated from the legal context.

\section{The Circulation of Asylum Talk at the Camp}

While waiting for their cases to be processed, asylum seekers in Denmark are housed in asylum centres_-camps' to the asylum seekers. These are located around the country, often some distance from urban centres. DIS is responsible for the accommodation and care of asylum seekers, but they subcontract this work to other organisations. Currently, the Red Cross operates about a third of Danish asylum centres, while municipalities run the remaining two-thirds. Unlike other countries, no private contractors run asylum centres in Denmark, though many are involved in catering, maintaining buildings, and security tasks.

Life at the camps is marked by the tight living conditions and the uncertainty of the asylum process. Asylum seekers often live four or more to a room with little or no privacy and very limited funds (called 'pocket money', paid out bi-weekly). They are restricted from working and pursuing education, while they wait. Their lack of money and the generally remote locations of the camps make mobility very difficult, so many asylum seekers simply sit and wait for the months or years it takes for their cases to be processed. The asylum system requires asylum seekers to participate in 'internships' [praktik] and other activities with the explicit goal of avoiding inactivity. However, these tasks often relate to cleaning, operation, and services at the asylum centre itself. They largely fail to counter the impression 
of stasis and wasting one's time prevalent among asylum seekers. In practice, the life of asylum seekers involved a great deal of sitting around, drinking tea, smoking cigarettes, playing pool, and watching tv, while waiting for news of their asylum case. This said, the common category, asylum seeker, tends to obscure the diversity of asylum seekers. Experiences of waiting (cf. Rotter 2016; Griffiths 2014) and of the asylum system more generally are fundamentally informed by the diversities of gender, age, class, health, ethnicity and so on.

At the same time, the asylum period is one of profound uncertainty for all asylum seekers. They wait while fundamental decisions about their future are made elsewhere in bureaucratic systems that are often opaque to them. This uncertain waiting takes its toll. As has been well established in the literature, extensive waiting times in the asylum period carry serious mental health consequences (Filges et al. 2016). However, they also impinge on social life at the asylum centres. Asylum seekers are unsure of the role the asylum centre operators have, and what their connection is to other asylum authorities, like the Immigration Service. This shapes their interactions with staff, who they worry may cause them problems but also hope may help their cases. They are also unsure of other asylum seekers, whose motives they may mistrust and who they are concerned may react unpredictably, because of the mental strains many are under. While social life among asylum seekers at the camps was thus at times strained, it nevertheless was an important part of most asylum seekers' daily lives. Most found friends, even if these were fleeting acquaintances, given the suddenness with which asylum seekers could move or be moved.

Asylum seekers seldom discussed their cases at the camps, and this was so for a number of reasons. First, the narratives presented to asylum authorities were often of a very personal and at times shameful nature. They might include experiences of humiliation, abuse, and even sexual assault. These were not stories to share with virtual strangers-nor indeed necessarily stories to share even with close family. Second, the experience of profound mistrust from asylum authorities and the fact that the narratives making up their cases were so to speak already in process made it a pragmatic point to keep quiet and wait for a decision. Third, many asylum seekers did not trust each other. There were everywhere stories about spies and enemies, also among compatriots and co-ethnics, who might use personal knowledge against the narrator and not least family in the home country. Fourth, some stories were embellished or outright constructed. Some asylum seekers presented narratives, which they had been told by smugglers or other people they trusted in this matter, were likely to gain them 'positive' decisions. 
Or they embellished stories in manners they thought or had been told were strategic. This did not necessarily indicate that they did not have a valid asylum claim, but it did certainly make this minority less likely to discuss these narratives in public (cf. Beneduce 2015).

For all their reticence about their individual cases, asylum seekers routinely discussed the asylum system itself. They talked about named caseworkers, but also the vulnerability of the system to random factors. As one asylum seeker nervously joked, 'Sometimes I think what if the person sitting with my case had a bad day. Maybe their dog was run over and they come to the office and then look at my application. How will they decide? Maybe on that day, everyone gets negative'. Similarly, we have heard versions of a story about two brothers seeking asylum from the same village for the same reasons, but where one got positive and the other negative, repeated across more than a decade. Further, there was an oft-expressed worry that asylum authorities were not able to distinguish truth from falsehood. Asylum seekers spoke of how 'people with real problems', who did not have the time and opportunity to go about finding corroborating evidence for their claims before they fled, were at a disadvantage to 'cheaters' because asylum authorities could not tell who was who. In other words, there was a widespread concern that the asylum system did not properly 'see' them (Whyte 2011; Kobelinsky, this volume).

And they spoke in detail about the problem of incompetent-or even malicious-interpreters. Stories abounded of interpreters who did not speak the language properly, who made unprofessional comments, or who simply seemed not to like the asylum seeker in question. This is part of a larger problem of interpretation in asylum hearings (Gibb and Good 2014; Pöllabauer 2004; Dahlvik, this volume), but also a specific problem in Denmark where a troubling number of court interpreters have been shown not to be up to their jobs (Christensen and Martinsen 2012; Graversen et al. 2015).

These kinds of conversations were a basic part of camp sociality: ways of interacting with other asylum seekers, who one did not know, in uncertain circumstances. One key aspect of this form of sociality at the camp was that the asylum seekers with most experience of the asylum system naturally were the ones who had waited the longest. But these were also a particular subset of asylum seekers, whose cases for one reason or another were dragging on. Asylum seekers were of course well aware of this, and people with a greater expectation of receiving asylum, often based on their country of origin, generally took these stories with a pinch of salt. 
But asylum talk can also be seen as an attempt to better understand the uncertainties of the asylum system, in much the same way as asylum seekers' discussions of the role and meaning of documents in Denmark (Whyte 2015). Many of these narratives were not necessarily coherent (Hyvärinen et al. 2010), but spoke in fragmented form to particular understandings of and attempts at understanding the asylum system. Unlike the required structuring of their asylum motives, concerns about consistency were not paramount, nor were the sources of these stories probed.

Walking back to the camp with Nazir, a young Afghan man, he started talking again about his waiting time:

I wait and wait and nothing happens here. I have been waiting 11 months now and still no interview, no letter, nothing. My friend told me that I should go to Norway, present all my papers there. They will send me back here, of course, but then they will have to give me a decision. What do you think?

This sort of plan was not uncommon and spoke to a common conception of having been forgotten. Reminding the asylum authorities of one's existence in one way or another might then reactivate the processing of one's case. But it was also considered dangerous, as it could cause annoyance and possibly delay matters further. Nazir was not convinced that it was a wise move. 'I talked to a man called Sader, some of the other Afghanis told me about him. He knows about these things, he has some kind of organisation to help Afghanis. He told me not to do it. He said it would make my case more complicated. But still [...]'.

Though not many asylum seekers necessarily carried out plans like these, they still returned to them time and again. This kind of asylum talk can be seen as a way of trying to find ways forward in an opaque system. Like attempts at procuring documents to strengthen one's case (Whyte 2015), Nazir's 'But still [...]' speaks to his desire to reclaim a sense of agency, to do something to advance his life. Unlike some others, Nazir recognised that this plan was not necessarily well-judged. But in any case it also had a significant social element. Connecting with and seeking advice from other people, also created and maintained certain forms of sociality prevalent at the camp. In that sense, asylum talk was both text and context for everyday life in the camps.

Discussions of the asylum system were often accompanied by sudden outbursts of anger and bitterness. 'I hear that in England they give passports even to their dogs. Their dogs! But here I cannot get positive. I get nothing. Negative. This is Europe: we think it is a democratic place, but for them us 
black-haired people are less than their dogs,' as a young Palestinian man said bitterly. Or as Abu Minna explained sitting in the kitchen at camp, his voice rising as he spoke about his interview with the Immigration Service, 'How can they tell me I am lying! They do not know my situation. I was in prison! The police beat me! Now this woman [the caseworker] talks to me as if I am a liar. I was so angry!'. His coffee cup quivered on the way to his lips. 'First they put us in this prison,' he waved his hand around the camp kitchen. 'Wait wait wait, every day. Every day, nothing. Then they treat us like liars. I get so angry!'

These attempts at understanding the asylum system went hand in hand with the emotional outbursts. And they were of course brought with them to the RAB, to which we now turn.

\section{Asylum Narratives at the RAB}

Having described the trajectory of the asylum motive and contrasted them with the asylum talk of the camp, we turn now to the RAB as a specific site of narrative judgment in which competing versions of asylum motives are presented, represented and performed.

In so doing, it is worthwhile establishing the 'stage' on which these performances take place. The RAB is made up of two waiting rooms for the asylum seekers, where lawyers have pre-meetings with their clients; one police room, where the lawyers and interpreters sit: one room for the lawyers (which is mainly used for discussing determinations with clients after the hearings); and one room for DIS representatives. In addition, there are rooms for the actual hearings.

The chairman always initiates the hearing by stating the rights and duties to the asylum seeker and explaining the process of the hearing. But a number of versions of the asylum motive co-exist and compete there. All of the written versions of the asylum motive across its trajectory are present in the paperwork. It is worth noting that the various interviews are not normally recorded (until recently asylum seekers were not allowed to record their own interviews), therefore it is not possible to go back and listen to the initial story to clarify any misunderstandings. The RAB is dependent on the written versions before them. On top of this, an oral version of the narrative is performed, when the lawyer interviews the client (through an interpreter) before the adjudicators, who also ask questions to illuminate the case. A representative from the DIS is also present to defend their rejection, though the vigour with which they do so varies significantly. While some only state, 'DIS recommends an affirmation of the rejection', others interview the 
asylum seeker again. These proceedings are taken down as minutes by a legal secretary. When all parties have had a chance to ask questions, the lawyer adds a new version in the form of the closing statement. This generally has the form of a competing reading of the various versions of the asylum motive, designed to explain possible discrepancies and to give the impression of consistency.

On the basis of this process and the various competing presentations of the asylum motive, the RAB renders its judgment. In so doing, it produces a final edition of the motive, which comes in two different written versions. The adjudicators in the RAB vote immediately after the hearing and draw up the final determination to the applicant. Besides the outcome of the case, it also consists of a summarised asylum motive as written by the legal secretary. This version can be found online as part of the 'RAB practice' in short form containing the asylum motive together with the outcome. The practice is important to refer to in future cases for both lawyers and adjudicators (RAB 2014).

While the various competing versions of the asylum motive are all important, a key part of the proceedings comes from the performance of the asylum seekers themselves. As a chairman explained: 'They [asylum seekers] can look alike when they are on paper, but the credibility impression can be very different [during the hearing in the RAB]'. This is a performance that their lawyers work hard to manage to ensure that the asylum motive steers clear of 'divergences' and appears 'self-experienced'. This is illustrated in an interview with Mette, talking about the meeting between the lawyer and the client:

'The meeting is about making [the clients] understand what it takes to get [the adjudicators] to believe their story. I explain how a story affects others. If you just sit and answer yes and no and if there are divergences, then you don't seem credible. You have to explain it down to the detail. You have to mention things that you only can say if you have experienced them yourself. For example 'and then he did this and then I thought that was strange...'. Or 'this officer wore these clothes, there were five stars on the shoulder...'. If he can make small descriptions of how it all adds up somehow. And then try to make them understand. It is also important that you can feel that it affects them to sit there and tell the story that you can feel that this is something they have experienced. It can be hard to make them understand. They also have a different cultural background for how to tell a story'.

For Mette, then, a successful presentation did not just involve telling the story coherently and avoiding divergences, but also had to be told in particular ways, involving the cultural repertoires of the narrator and the audience (Eastmond 2007: 249). Mette tried to make her clients understand that the judges had to 'feel' that the applicant was actually there through 
the performance of the narrative. This embodiment of the narrative was not something that all asylum seekers practised in a way that was appreciated by the adjudicators, as indicated by the quote. What Mette was implying was that representation is also about instructing the asylum seekers in the importance of presenting the asylum motive in an appropriate way. That is, using the body to convince the $\mathrm{RAB}$, during the actual hearing, that it is in fact 'self-experienced'.

One of the problems facing lawyers in this endeavour is the built-up frustration, fear, and anger of the asylum seekers. Hanne was representing a couple from Iran with a young daughter. The mother was crying in the asylum seekers' waiting room, as Hanne was in the midst of the pre-meeting with her client. She turned to the mother: 'You really ought to stop crying. It doesn't pay off to cry in front of the Board; you don't win anything by doing that'. Here it becomes clear that the anger and frustration that is so evident in the camp-in the asylum talk - cannot be exposed in the RAB. It is to be separated from the legal procedure and assessment of the asylum motive even though, for the asylum seekers, these contexts are inseparable. In other words, while it was important for asylum seekers to convey feelings about their past in an appropriate way, it was equally important to keep their feelings about their present hidden away.

Before the Board, the husband explained that the police in Iran had held him back, and that their home had been searched several times. Hanne interrogated him about the incidents in his home: 'What happened exactly when the police came to your house? How many officers were there? (Client/interpreter): 'There were many; maybe four. They held me like this' [the client gets up, takes his arms together on the back to show that he was handcuffed. He bends down, indicating that they pushed his head towards the floor]. 'They searched my house for flyers; everything was torn into pieces. That happened several times'.'

After the hearing, Hanne seemed satisfied: 'They really explained themselves well; you really felt like you were present. That is really good'. After a short waiting time we were called back into the hearing room. The adjudicators stressed that the explanation seemed 'self-experienced' and was thus 'accepted'. The couple was granted asylum. Both the lawyer and adjudicators thus emphasised the performance of the narrative as a decisive factor.

For asylum seekers, this experience was often demeaning. Many experienced the court setting in highly moral terms as a space in which they were mistrusted and even accused of dishonesty. As one young Afghani man said, as he returned to the RAB waiting rooms, shaking with anger, 'They didn't believe me! That man [from the Immigration Service] spoke lies about my 
father! He said I was lying!'. His older brother, whose case was being heard with him, looked slightly stunned himself, cheeks flushed, but put his hand on his brother's shoulder. 'Wait, just wait'. 'I wanted to punch him. How can he sit and lie like that? And the lawyer! He said nothing!'.

\section{Conclusion}

As will be evident from this description, camps and courts provide two radically different narrative contexts for asylum seekers. They are connected by the asylum seekers themselves of course, but also by the negotiations of legal and moral judgements that frame the two contexts. While the RAB sees itself as making legal judgements on specific cases, it seems clear that they also take account of a range of extra-legal factors from credibility to performance. For asylum seekers, these factors tend to loom large and often formed grist for the mill of their asylum talk.

At court, asylum seekers' asylum motives are significantly formed in interaction with powerful interlocutors and re-presented by their lawyers. While asylum seekers remain responsible for these narratives, in the sense that they are the ones who bear the consequences of the RAB's decision on them, the motives are also significantly beyond asylum seekers' control. Asylum motives are attributed to asylum seekers but are not necessarily fully theirs in an experiential sense. Indeed, as we have argued, the performative requirements put on them may tend to leave little space for their own sense of presence at the court. They tend not to feel heard or understood throughout the asylum determination system. However, the right kind of performance, the embodiment of the narrative, can in some cases overrule a narrative that was previously in the procedure considered not credible-when it affirms the 'self-experience' of the incidents expressed. By contrast, in the camp, asylum seekers are all too frustratingly present. They feel they are wasting their time there, waiting for their cases to move forward. But they do not generally discuss their asylum motives at the camp, instead engaging in what we have called 'asylum talk' through which they attempt to make sense of the seemingly opaque asylum process they are in together.

\section{References}

Beneduce, R. (2015). The Moral Economy of Lying: Subjectcraft, Narrative Capital, and Uncertainty in the Politics of Asylum. Medical Anthropology, 34(6), 551-571. 
Blommaert, J. (2001). Investigating Narrative: African Asylum Seekers' Stories in Belgium. Discourse and Society, 12, 413-449.

Bohmer, C., \& Shuman, A. (2008). Rejecting Refugees: Political Asylum in the 21st Century. London and New York: Routledge.

Bohmer, C., \& Shuman, A. (2010). Narrating Atrocity: Uses of Evidence in the Political Asylum Process (DIIS Working Paper, 25). DIIS.

Bruner, E. M. (1986). Experience and Its Expressions. In V. W. Turner \& E. M. Bruner (Eds.), The Anthropology of Experience (pp. 3-33). Chicago: University of Illinois Press.

Christensen L. B. et al. (2006). Udlændingeret. 3. udgave, 1. oplag. København: Jurist- og Økonomiforbundets Forlag.

Christensen, T. P., \& Martinsen, B. (2012). Retstolkens rolle-En sporgeskemaundersogelse blandt danske domstolsjurister om deres forventninger til og oplevelser med retstolke. Research Report, Aarhus University, Business and Social Sciences, Department of Business Communications.

Colson, E. (2007). Linkages Methodology: No Man is an Island. Journal of Refugee Studies, 20(2), 320.

Coutin, S. B. (2001). The Oppressed, the Suspect, and the Citizen: Subjectivity in Competing Accounts of Political Violence. Law and Social Inquiry, 26(1), 63-94.

Daniel, E. V., \& Knudsen, J. C. (1995). Mistrusting Refugees. Berkeley: University of California Press.

DAA, The Danish Aliens Act. (2016). Available at: https://www.retsinformation.dk/ Forms/R0710.aspx?id=180093. Accessed 7 Dec 2016.

DIS. (2013). Tal og Fakta. Udlændingestyrelsen. Nyidanmark. Available at: http://www.nyidanmark.dk/NR/rdonlyres/2934917B-F967-4EDF-BEDF753D190BA6C2/0/tal_og_fakta_2012.pdf. Accessed 3 Jan 2014.

Eastmond, M. (2007). Stories as Lived Experience: Narratives in Forced Migration Research. Journal of Refugee Studies, 20(2), 248-264.

Filges, T., Montgomery, E., \& Kastrup, M. (2016). The Impact of Detention on the Health of Asylum Seekers: A Systematic Review. Research on Social Work Practice (pp. 1-17).

Ghorashi, H. (2008). Giving Silence a Chance: The Importance of Life Stories for Research on Refugees. Journal of Refugee Studies, 21(1), 117-132.

Giordano, C. (2008). Practices of Translation and the Making of Migrant Subjectivities in Contemporary Italy. American Ethnologist, 35(4), 588-606.

Gibb, R., \& Good, A. (2014). Interpretation, Translation and Intercultural Communication in Refugee Status Determination Procedures in the UK and France. Language and Intercultural Communication, 14(3), 385-399.

Good, A. (2007). Anthropology and Expertise in the Asylum Courts. New York: Routledge-Cavendish.

Graversen, C., Jacobsen, B., \& Nørgaard A-J. (2015). Tolkning i den offentlige sektor. Den aktuelle tolkesituation. Afrapportering af sporgeskemaundersøgelse blandt tolkebrugere i den offentlige sektor. Copenhagen: Translatørforeningen. 
Griffiths, M. (2014). Out of Time: The Temporal Uncertainties of Refused Asylum Seekers and Immigration Detainees. Journal of Ethnic and Migration Studies, 40(12), 1991-2009.

Hyvärinen, M., Hydén, L.-C., Saarenheimo, M., \& Tamboukou, M. (Eds.). (2010). Beyond Narrative Coherence. Amsterdam: John Benjamins.

Kjær, K. U. (2001). Bevissituationen i Asylsager. Karnov Group Denmark (pp. 1-5).

Kälin, W. (1986). Troubled Communication: Cross-Cultural Misunderstandings in the Asylum-Hearing. International Migration Review, 2(2), 230-241.

Kobelinsky, C. (2015). Emotions as Evidence. An Ethnographic Exploration of Hearings in the French Asylum Courts. In D. Berti, A. Good, \& G. Tarabout (Eds.), Of Doubt and Proof: Ritual and Legal Practices of Judgement. London: Ashgate.

Krulfeld, R. M., \& MacDonald, J. L. (1998). Power, Ethics, and Human Rights: Anthropological Studies of Refugee Research and Action. Oxford: Rowman and Littlefield.

Maryns, Katrijn. (2006). The Asylum Speaker: Language in the Belgian Asylum Procedure. Manchester: St. Jerome.

McKinley, M. (1997). Life Stories, Disclosure and the Law. PoLAR, 20, 70-82.

Omidian, P. A. (1994). Life Out of Context: Recording Afghan Refugees' Stories. In L. A. Camino \& R. M. Krulfeld (Eds.), Reconstructing Lives, Recapturing Meaning: Refugee Identity, Gender, and Culture Change. Amsterdam: Gordon and Breach.

P1, Hvad der skete siden? (2014). [Documentary], P1 Dokumentar, See: http:// www.dr.dk/radio/ondemand/p1/p1-dokumentar-94\#!!. Accessed 5 Jan 2014.

Pöllabauer, S. (2004). Interpreting in Asylum Hearings: Issues of Role, Responsibility and Power. Interpreting, 6(2), 143-180.

RAB. (2014). Flygtningenavnets praksis. Available at: http://fln.dk/da-dk/Praksis. Accessed 23 Mar 2014.

Rotter, R. (2016). Waiting in the Asylum Determination Process: Just An Empty Interlude? Time and Society, 25(1), 80-101.

Smith, K. (2015). Stories Told By, For, and About Women Refugees: Engendering Resistance. ACME: An International E-Journal for Critical Geographies 14(2), 461-469.

Smith, K. (2016). Telling Stories of Resistance and Ruination: Women Seeking Asylum. Journal of Resistance Studies, 4(2), 33-64.

Vogl, A. (2013). Telling Stories from Start to Finish: Exploring the Demand for Narrative in Refugee Testimony. Griffith Law Review, 22(1), 63-86.

Whyte, Z. (2011). Enter the Myopticon: Uncertain Surveillance in the Danish Asylum System. Anthropology Today, 27(3), 18-21.

Whyte, Z. (2015). In Doubt: Documents as Fetishes in the Danish Asylum System. In B. Berti, A. Good, \& G. Tarabout (Eds.), Of Doubt and Proof: Ritual and Legal Practices of Judgement (pp. 141-162). Farnham: Ashgate. 
Open Access This chapter is distributed under the terms of the Creative Commons Attribution 4.0 International License (http://creativecommons.org/licenses/ by/4.0/), which permits use, duplication, adaptation, distribution and reproduction in any medium or format, as long as you give appropriate credit to the original author(s) and the source, a link is provided to the Creative Commons license and any changes made are indicated.

The images or other third party material in this chapter are included in the work's Creative Commons license, unless indicated otherwise in the credit line; if such material is not included in the work's Creative Commons license and the respective action is not permitted by statutory regulation, users will need to obtain permission from the license holder to duplicate, adapt or reproduce the material. 